\title{
KETTU, KOIRA VAI APILA? \\ Sukupuolettomuuden mahdollisuuksista suomalaisessa nykyfiktiossa
}

Joonas Säntti

Arkielämä pakottaa meidät jatkuvasti tilanteisiin, joissa kaksijakoiselle sukupuolelle annettu symbolinen hyväksyntä on ainoa tapa siirtyä eteenpäin. Esimerkiksi valitessani vessanovea, varatessani junamatkaa Keski-Eurooppaan, täyttäessäni milloin mitäkin valtiovallan edellyttämää kaavaketta ja selontekoa tai antaessani palautetta kuluttajakyselyyn, virallisen sukupuoleni tunnustamisen vaatimus jyrää varmuuteni siitä, että sillä ei tulisi juuri tuossa tilanteessa olla mitään merkitystä.

Monille tällaiset arkiset tilanteet saattavat herättää voimakkaita aggression ja epätoivon ailahduksia. Totisesti, "liian monta rasti ruutuun -lomaketta on tullut vastaan", kuten Eeva Turusen novellin "Näyttävä heinäsorsakoiras juhlapuvussaan" kertoja toteaa. Neitiherraksi esittäytyvä kertoja esittelee seuraavan vaihtoehdon: "Tässä sinulle lomake, joka on hyvin yksinkertainen täyttää". Minuuden määrittelyn vaihtoehdoiksi tarjotaan humoristisesti koiraa, kettua ja apilaa.

Novellin fantasiavalikossa on paljon tuttuakin, esimerkiksi se, että rastitettavia ruutuja on juuri kolme, joka vastaa nykyhetken yleisintä ei-binäärisen huomioivaa kaavaketta (mies/nainen/muu). Tietystä absurdismistaan huolimatta näissäkin esimerkeissä on oma järjestelmällisyytensä: kahden eläinkunnan edustajan vastapainoksi kolmas onkin sitten jotain muuta, vegetaalijengin jäsen. Kenties jakson puhuttelevuus liittyy siihenkin, että siirtymä kahdesta kolmeen ei varsinaisesti vapauta rastittajaa kategorioiden vallasta. Voiko kirjallisuus ja kieli sitten tarjota paikkaa ja tilannetta, jossa päästäisiin eroon rastittamisesta?

Esseessäni pyrin tarkastelemaan 2000-luvun kirjallisuudessa näyttävästi yleistyneiden sukupuoleltaan hankalasti määriteltävien henkilöiden ja kertojien merkitystä. Pohdin miksi juuri sukupuolen paikantamista hankaloittavat ja sukupuolieroa monimutkaistavat tekstit ovat tärkeitä nykyhetkessä. Miksi lukijan olisi syytä kunnioittaa tätä monitulkintaisuutta, kenties jopa aktiivisesti pidättyä rakentamasta sille selittävää hypoteesia?

Oma akateeminen taustani on kertomustieteessä ja olen erityisesti kiinnostunut feministisestä queer-narratologiasta, jossa etsitään vaihtoehtoja vakiintuneiden kertomustieteellisten suuntausten eksplisiittisesti ja implisiittisesti normatiivisille tavoille jäsentää sukupuolta ja seksuaalisuutta (Warhol \& Lanser 2015). Tutkijana minua puhuttelevat erityisesti tekstit, joissa binärismin haastaminen yltää sukupuolieron käsitteen tasolle. Näissä teksteissä sukupuoliero ei siis liity vain sosiaalisiin identiteetteihin tai rooleihin, vaan laajemmin sukupuolisuuden monitulkintaisuuteen. Kyse ei ole jostain tietystä lokalisoidusta anti-binäärisestä identiteetistä 
- muunsukupuolisuudesta, transsukupuolisuudesta, genderqueeristä vaan paikantumattomuudesta, keskenään ristiriitaisten ja arkikokemuksen kannalta usein yhteensovittamattomien vaihtoehtojen tuottamisesta (sana) taiteelle ominaisilla keinoilla.

Eräs mahdollisuus liittyy tietysti spekulatiivisen fiktion kuvittelemiin toisiin maailmoihin. Luomalla utopioiden ja dystopioiden sijaan heterotopioita eli paikkoja, joissa ilmiöiden erot ja jäsentyvät tuntemastamme logiikasta eroavalla tavalla, voidaan myös vieraannuttaa nykytodellisuutta, osoittaa vallitsevien olojen keinotekoisuus ja sattumanvaraisuus. Kuten filosofi Michel Foucault toteaa, heterotopiat "häiritsevät" koska yhdistäessään yhteensopimattomia ilmiöitä ne "jäytävät kielen perustuksia, estävät nimeämästä tätä ja tuota” (Foucault 2010, 15). Luonnehdinta sopii esimerkiksi Maria Matinmikon runoromaaniin Kolkka (2019), jonka harsoinen, sotkuinen ja runokielen tapaan näennäisiä vastakohtaisuuksia toisiinsa sulauttava ilmaisu tuottaa ainakin hetkittäin tuollaista epävarmuutta. Mielestäni ainakin osa näistä mahdollisuuksista aktivoituu myös käyttämällä vähemmän fabuloimiseen perustuvaa kerronnan elettä: sukupuolittavien elementtien välttämistä tai keskenään ristiriitaisten koodien hyödyntämistä päähenkilön kuvauksessa tai henkilö-kertojan diskurssissa. Sukupuolen "purkaminen kertomalla", joka on yksi Matinmikon pyrkimyksistä, ei välttämättä edellytä matkaa nep-nepiirien maahan.

Varsinkin romaanin mittaisessa proosatekstissä keskeisen fiktiohenkilön sukupuolen avoimeksi jättäminen edellyttää esimerkiksi olemuksen äärimmäistä pelkistämistä tai vastakohtaisesti ylenpalttista, ristiriitaista kuvailua. Niinpä tuntuu luontevalta ajatella fiktiohenkilöiden sukupuolista monitulkintaisuutta kirjailijan tietoisena strategisena valintana. Samalla on syytä miettiä niitä ehtoja, jotka rajaavat tällaisten taiteellis-poliittisten strategioiden tunnistamista ja esille lukemista.

\section{Tarinamallien epäluonnollistaminen}

Tekstit, joissa sukupuolen monitulkintaisuus tarkoittaa usean vaihtoehdon samanaikaisuutta, epäluonnollistavat kulttuuristen tarinoiden vakiintuneita sukupuoliasetelmia. Niinpä Anu Kaajan Ledan (2017) tirkistely- ja väkivaltafantasioita patriarkaaliseen naisten torumiseen yhdistävä kertoja ja Laura Lindstedtin Ystäväni Natalian (2019) heikosti toisia kuunteleva ja ymmärtävä, hieman ylimielisesti setäselittävä psykologi voivat tulla luetuiksi myös naisina. Pornografinen hameen alle kurkistelu ja feminisoidun ruumiin spektaakkelista nauttiminen eivät rajoitu miesoletettuihin. Yleisinä väittäminä nämä eivät ole ennenkuulumattomia, tuntuvat ehkä itsestään selviltäkin: no totta kai nainenkin voi tehdä tai ajatella noin! Pitkän fiktiotekstin lukemisprosessiin kuitenkin liittyy välttämättä kulttuuristen koodien ja kehysten hyödyntämistä, ennakointia ja ennakko-oletusten uudelleentarkistamista, ehkä myös voimakasta affektiivistä eläytymistä. Niinpä tunne tekstin vastahankaisuudesta on huomattavasti syvempi ja vaikuttavampi.

Kuten kertomustieteilijä H. Porter Abbott $(2013,3-4)$ toteaa, kertovien tekstien tuottama hämmennys voi olla "kouriintuntuvaa": se, että ymmärrämme jonkin olevan yleisesti tietomme ulkopuolella, ei ole sama asia kuin kokemus omasta tietämättömyydestä jatkuvana olotilana ("to be immersed in the condition of unknowing"). Abbott ei käsittele sukupuolta, mutta mielestäni samaa ajatusta voi hyödyntää tässä kontekstissa. Varsin harvoin teksti mahdollistaa pitkäkestoisen kokemuksen siitä, että henkilön sukupuoli vastustaa lukijan tulkinnallisia pyrkimyksiä.

Lindstedtin romaanin henkilö-kertoja, vuolaaseen kuvailuun taipuvainen psykologi, aloittaa Ystäväni Natalian toisen luvun näillä sanoin: "Natalialla - jonka nimestä poistan nyt lainausmerkit niin kuin poistaisin aseestani varmistimen - oli arkielämää suuresti häiritsevä ongelma.” (Lindstedt 2009,9.)
Pervopeili Artikkelit 
Mitkä seikat saavat minut tässä vaiheessa kuvittelemaan kertojan tässä kohtaa mieshahmoiseksi? Aseeseen ja ampumiseen viittaaminen ei ole tässä niin olennainen kuin se mitä voi päätellä kertojan tavasta rakentaa vertaus näin uhkaavaan sävyyn - puhumattakaan väkivaltaisen kielikuvan häiritsevyydestä juuri tässä yhteydessä, psykologin asiakkaastaan esittämänä. Tilanne on helppo yhdistää psykopaattisuutensa kätkevän miesrikollisen hahmoon, joita koskevia kertomuksia populaarikulttuuri on tulvillaan.

Muutamaa sivua myöhemmin kertoja kuvailee asiakkaansa itkemisen tuottamaa esteettistä elämystä. Vaikka kertoja toistuvasti vakuuttaa kyvystään empatiaan, hän tarkastelee Nataliaa taideteoksen tapaan: "kun Natalia alkoi itkeä, aistin voimallisesti kauneuden läsnäolon." Asiakkaan tunteenpurkaus tarjoaa harmonisen näyn siitä huolimatta, että "hänen silmiensä ja suunsa välinen etäisyys oli pidempi kuin mitä kauneuden tieteellisesti todistettu kaava olisi sallinut". (Lindstedt 2019, 12-13.)

Feministisesti orientoituneen tutkijan on helpompi otaksua, että naisen objektivoimisesta ja naisruumiin tarjoamasta spektaakkelista nautiskeleva subjekti on mies - tai vähintään maskuliinisen katseen omaksunut ihminen. Queer-tutkimus on toisaalta usein pyrkinyt todistamaan tällaisten asetelmien historiallisen ja paikallisen vaihtelevuuden. Esimerkiksi naisten välisiä suhteita viktoriaanisessa Englannissa käsitellyt Sharon Marcus kyseenalaistaa oletuksen siitä, että pornografian subjekti/objekti-asetelmat seuraisivat suoraan kulttuurin muista valta-asetelmista.

Marcus toteaa suorasanaisesti, että naiset saivat nautintoa objektivoitujen ihmishahmojen katsomiseen liittyvästä ylemmyyden tunteesta siinä missä miehetkin (Marcus 2007, 120). Viktoriaanisen pornografian ohella nukkekulttuurin ja naisyleisölle osoitettujen, usein naisten tekemien muotikuvien analyysissään Marcus kritisoi "edelleen vaikutusvaltaista" näkemystä, jonka mukaan voyerismi on ollut vain miessubjektille varattu asema, että "miehet katsovat ja naisia katsotaan" (Marcus 2007, 135). Miten paljon nykyisessä feministisessä proosassa harrastetaan juuri tällaisten oletusten luonnollistamista mieskatseen kritiikin muodossa?

Henkilöhahmon sukupuolen pimittäminen ei tietysti välttämättä ole feministinen strategia. Kokonaisteoksina Leda ja Ystäväni Natalia käsittelevät kuitenkin nimenomaan henkisen ja fyysisen väkivallan sukupuolittuneita muotoja. Ledassa kurkistellut, kuritetut ja raiskatut ovat suurimmalta osin naisia. Lindstedtin romaanin nimihenkilö on usein äärimmäistä feminiinisyyttä performoiva nainen, jonka pitkien monologien kautta kommentoidaan ironisesti tunnustamisen ja minäpuheen retoriikkaa, sukupuolen mystifioimista ja naisruumiin asemaa psykoanalyysin historiassa. Kaajan ja Lindstedtin teoksissa valta-asetelmia käsitellään tavalla, jossa huomio kiinnittyy tekoihin ja niiden kantamiin sukupuolihistorioihin, mutta patriarkaalista valtaa ei ole turvallisesti siirretty miehen hahmoon. Henkilön olemusta ei voi päätellä sen perusteella, että hän tirkistelee naisia "jäykistyneenä” tai analysoi surkuhupaisan ymmärtämättömästi asiakkaansa oletettua peniskateutta.

Molemmat romaanit käyvät esimerkkeinä siitä, miten vahvasti sukupuolen tulkinta kytkeytyy seksuaalisuuteen. Ledan kehyskertomuksessa kirjoittamisen ja lukemisen halu sidotaan asetelmaan, jota on vaikea olla sukupuolittamatta: nimeämättä jätetty kertoja puhuttelee kirjeissään nimeämättä jäänyttä vastaanottajaa ja kehottaa tätä nauttimaan kertomuksestaan, jossa viaton neitsyt "vietellään" ja "häpäistään". 1700-luvulle sijoitetussa kertomuksessa luokkaetuoikeudet, kuten oikeus tehdä "kasvottomalle palvelusväelle" omien halujensa mukaan, kuitenkin monimutkaistavat tarinamaailman tilanteita, jotka metoon värittämässä nykyhetkessä yhdistyisivät ehkä suoraviivaisemmin himokkaan miessubjektin ja naisuhrin valmiisiin kertomusmalleihin.

Ystäväni Nataliasta poimitut esimerkit kertovat toisaalta yksittäisten jaksojen analyysiin liittyvistä vaaroista. Miten kertojan sukupuoleen liittyvää 
ristiriitaisuutta voi lähestyä muuten kuin todistamalla sitä vastakohtien kautta, toisin sanoen sukupuolittamalla esityksen osia? Jos osoittaa kertojan diskurssista toisaalta maskuliinisia, toisaalta feminiinisiä piirteitä, tuleeko silloin tarkoittamattaan vahvistaneeksi noiden paikannusten itsestäänselvyyttä? Miten käsitellä poikkeuksia muuten kuin sääntöä vahvistavina?

Esimerkkinä siitä, miten ilmiöön perehtynyt tutkijakin saattaa päätyä esittämään omituisen konservatiivisia paikannuksia, voi mainita Monika Fludernikin vuonna 1999 julkaistun artikkelin sukupuoleltaan määrittelemättömien ensimmäisen persoonan kertojista. Narratologinen tarkkuus yksityiskohtien ruotimisessa ohjautuu esittämään ehdotuksia kaikista niistä tavoista, joilla kulttuurinen tietomme auttaa sijoittamaan merkkejä sukupuolijärjestelmään. Esimerkiksi: kun kertoja ryöstetään kadulla, tekstissä ei ole erikseen mainintaa hänen käsilaukustaan tai raiskauksen uhkasta. 1960-luvun romaanihenkilö, joka on hyvä uimaan, kiipeilemään ja rakentamaan työkaluja, olisi todennäköisemmin mies kuin nainen. (Fludernik 1999.) Sukupuoli olisi näin ajateltuna mysteeri vain siinä mielessä, että se odottaa tarkan lukijan "ratkaisua". On kuin lukija ei kestäisi epävarmuutta, joka jatkuu yli kirjan viimeisen sivun.

Jeanette Wintersonin romaani Written on the Body (1992, suom. Ihoon kirjoitettu) on erityisen maineikas esimerkki kertomuksesta, joka jättää sukupuoliasetelmien määrittämisen lukijan vastuulle. Sillä on erityisasema myös poliittisessa ja kontekstualisoivassa kertomustieteessä, koska romaanin kertojaa käsittelevä Susan Lanserin artikkeli vuodelta 1995 tavataan mainita eräänä queer-narratologian alkulähteenä. Kuten Lanser toteaa, lukijan on hämmentävän helppoa olla huomaamatta tekstin kertojan erikoisuutta. Winterson oli teoksen ilmestymisen aikoihin eräs tunnetuimmista nuorista brittikirjailijoista, ja koska hänet tunnettiin nimenomaan omaelämäkerrallisia aiheita sivuavana "lesbokirjailijana", kertoja haluttiin tässäkin tapauksessa jo olettaa naishahmoiseksi. Kenties vielä suurempaa osaa lukijoista ohjasi erilainen ennakko-oletus: jos romaani esittää kolmio- draaman, jossa päähenkilö on rakastunut naimisissa olevaan naiseen, tuo päh̆henkilö tulee kulttuurisesti vakiintuneiden kertomusmallien vuoksi automaattisesti luettua mieheksi. (Lanser 1996, 252-258.)

Käsitellessäni Wintersonin romaania ja artikkelia opetusryhmissä aloin miettiä mahdollisuutta lukea tekemättä valintaa. Jos kirjaa lukiessa visualisoi henkilöhahmon, kuten realistisen proosatekstin kohdalla lukijat yleensä tekevät, miten keskenään ristiriitaiset vaihtoehdot voivat käytännössä aktivoitua - muuten kuin eri lukemiskertoihin jaksotettuina?

\section{Laajennetun sukupuolivalikon rajoitukset}

1900-luvun ranskan- ja englanninkielisen kirjallisuuden kontekstissa sukupuoleltaan monitulkintaiset henkilöt liittyivät usein kokeelliseen kirjallisuuteen, erityisesti pyrkimykseen rikkoa romaanisten kielten sukupuolitettua ja tässä mielessä sekä ilmaisua rajoittavaksi että feminiinistä väheksyväksi koettua sanastoa. Natalie Barneyn, Monique Wittigin, Maureen Duffyn ja Anne Garretan kaltaisten kirjailijoiden teoksissa (sukupuoli) poliittinen ja kirjallinen avantgarde eivät olleet siististi eroteltavissa. (Ks. Livia 2001, 3-30.) Avantgarde-kirjallisuuden lisäksi sukupuolitetuilla persoonapronomeilla ja päähenkilöiden sukupuolella leikittelevää proosaa kuitenkin esiintyi myös populäärikirjallisuuden genreissä, kuten dekkareissa ja scifissä. Niinpä Anna Livia $(2001,20-21)$ saattoi jo vuosituhannen vaihteessa todeta, että kyseessä oli vakiintunut kaunokirjallinen ilmiö. Arvelen, että nyt parikymmentä vuotta myöhemmin, kirjailijoiden ja lukijoiden kiinnostukseen ei voi olla vaikuttamatta esimerkiksi trans-ihmisten runsaampi näkyvyys tai tietoisuus erilaisten sukupuoli-identiteettien yleistymisestä. Kirjoittaessaan 1990-luvun puolivälissä Lanser otaksui lukijoiden yleensä tuntevan ”ahdistuneisuutta" (anxiety) niistä tapauksista, joissa kertojahahmon ja/tai tekijän sukupuolta ei voinut varmasti tietää $(1996,252)$. Mahtaisiko tämä olla pikkuhiljaa muuttumassa? 
Garreta taustoitti oman romaaninsa (Sphinx, 1986) henkilöiden sukupuolisten merkkien poistamista menetelmälliselle kirjoittamiselle ominaisena rajoituksena, mutta myös lukijoille viritettynä "ansana", joka pyrki tekemään lukijalle näkyväksi tämän omat oletukset (Livia 2001, 32).

Ajatusta laajentaen voisi ehdottaa, että ratkaisun lähes itsestäänselvyytenä harjoitettu vastakohta, sukupuolen "antaminen" fiktiohenkilölle, on sekin eräänlainen rajoitus, enemmän tai vähemmän keinotekoinen. Kirjailija Meri Kuusisto ihmettelee kirjailijaliiton verkkosivun haastattelussa: "Miksi päähenkilöllä pitäisi edes olla sukupuolta?” (Hiidensalo 2019). Suoraviivainen kysymys on pitemmän pysähtymisen arvoinen: miksi tosiaan? Hankalasti sukupuolitettavien hahmojen näkyvyyden kasvu 2000-luvun suomalaisessa proosassa ei ole yllättävä. Erikoisempaa lienee se, että ilmiö ei suomenkielisessä kirjallisuudessa ole vielä yleisempi. Onhan tämä niitä harvoja kieliä, joissa esimerkiksi virallisen kieliopin mukaiset persoonapronominit eivät sukupuolita "häntä".

Uskon, että fiktion parissa kohdattu kysymys tai tulkinnallinen haaste alkaa sihlautua lukijoiden arkeen, varsinkin usein toistuessaan. Sukupuolittamista hankaloittava fiktio hidastaa, jos ei täysin estä, olettamista ja olemuksellistamista. Näin se voi ohjata muistamaan, että todellisten ihmisten kohtaaminen sisältää tulkintaa, jossa turvaamme stereotypioihin. Hahmotanko jotkut tunteista puhumisen tavat automaattisesti "naisen puheeksi" ja ovatko mielikuvani tietyistä ammateista, toiminnoista ja käytösmalleista huomaamattani täysin sukupuolitettuja? Mihin nämä oletukset oikeastaan perustuvat ja voiko niitä muuttaa kirjoittamisen kautta? Kuten Judith Butler teoksessaan Undoing Gender $(2004,213)$ kysyy: "Is the symbolic eligible for social intervention?"

On helppo edelleen allekirjoittaa Gayle Salamonin (2010, 95-96) vuosikymmenen takainen väite siitä, että akateeminen sukupuolentutkimus ei ole osannut käsitellä sukupuolen moninaisuutta sellaisena kuin se ny- kyisessä arjessa eletään. Kaunokirjallisuus on ollut tässäkin edelläkävijä. Näkisin, että kirjoituksella on uudelleenjäsentämisessä erityinen valttinsa, joka liittyy itse kielen luonteeseen, sen kykyyn peittää ja kerrostaa, tuottaa kuvailua joka on etäällä arkisesta kokemuksesta ja visuaalisesta havainnosta. Kirjoitetun fiktion suuria mahdollisuuksia on tulkinnanvaraisuuden kasvattaminen kätkemisen kautta. Englanninkielisessä kirjallisuudentutkimuksessa yleisesti käytetty "voice" herättää helposti konnotaatioita jonkun puheäänen kuuntelemisesta. Kertojan "ääni” on kuitenkin äärimmäisen metaforinen ilmaisu lähtökohtaisesti hyvin epäluonnolliselle tilanteelle, puhumattakaan kirjallisuuskritiikeissä usein viitatusta kirjailijanäänestä.

En halua sokeasti ylimainostaa kirjoittamisen ja lukemisen tuottamaa vapautta. Ajatus sukupuolesta "kertomuksena, jonka jokainen kertoo itsestään" on kaunis, mutta puhtaasti utopistinen. Kuka kuuntelee ja kuka on kiinnostunut ymmärtämään? Kertominen tapahtuu aina tilanteessa, jossa vain jotkut kertomisen mallit ovat ylipäätään ajateltavissa ja tunnistettavissa legitiimeiksi - seikka jota konstruktionistiset sukupuoliteoriat nähdäkseni eri painotuksin korostavat. Tarkoitukseni ei myöskään ole kyseenalaistaa fiktiohenkilön identiteetin paikantamista yhtenä mahdollisena valintana. Monessa tapauksessa ymmärrys teoksesta ja sen poliittisesta merkityksestä muuttuu paljonkin sen perusteella, luetaanko jokin tekstijakso transvestiitin tai transnaisen, butch-lesbon tai transmiehen kokemuksia kuvaavaksi.

Uskon silti, että ristiriitaisia mahdollisuuksia samanaikaisesti tarjoavilla sanataideteoksilla on erityinen, juuri queeriin verbinä - aktiivisena vaikeuttamisena ja pervouttamisena - kytkeytyvä radikaali ulottuvuutensa. Ne ohjaavat kohtaamaan nimeämisen mielivaltaisuuden voimakkaammin kuin tekstit, joissa selkeästi sukupuolitetuille fiktiohenkilöille annetaan yllättäviä feminiinisiä tai maskuliinisia piirteitä. Ne erottuvat tässä myös teoksista, joissa käsitellään selkeämmin transmiehen tai transnaisen kokemuksia. Tuntuisi jokseenkin hyödyttömältä alkaa erotella sitä, miten 
Anu Kaajan Ledan merkitys muuttuisi sen mukaan, tulkitseeko kertojan harjoittavan satunnaista ristiinpukeutumista vai paljastavan jotain syvemmästä transidentiteetistä - puhumattakaan siitä millaista sokeutta olisi nimetä 1700-luvulle sijoitettuja fiktiohahmoja 2000-luvun sukupuolikategorioista käsin.

Keskusteluun tällaisten representaatioiden ja kaunokirjallisen kuvittelun poliittisesta merkityksestä vaikuttaa myös queerin ja transin välinen suhde, joka on 2000-luvulla osoittautunut ehkä yllättävänkin hankalaksi. Susan Stryker kritisoi queer-teoriaa seksuaalisuuden ylikorostamisesta ja siitä että "queer" muuttui nopeasti normatiivisen sukupuolen kritiikistä peitenimeksi homo- ja lesboaiheiden käsittelylle. Transsukupuolisuuden käsittelyä ei Strykerin mukaan tulisi palauttaa vain yksilöiden identiteetin tasolle, vaan sitä tulisi laajentaa huomioimaan kaikki ne tavat, joilla normatiivisen sukupuolen luonnollisuutta ja historiattomuutta haastetaan. (Stryker 2004, 213-214; 2014, 40.) Näin kriittinen transgender-teoria voisi ikään kuin lunastaa queerin lupaaman mutta sivuuttaman projektin. Edelleen queer-teoriaa on kritisoitu tavasta eristää transsukupuolisuus alueeksi, johon koko sukupuolieron ongelmallisuus voidaan turvallisesti palauttaa, jotta sitä ei tarvitsisi analysoida kaikkien sukupuoli-identiteettien kohdalla. Näin trans on suljettu ulkopuolelle siitä mikä on todellista ja elintärkeää myös queer-feminismin kannalta. (Salamon 2010, 100-102.)

Nykyhetkessä kuitenkin myös trans-aktivismi ja välillä myös trans-teoria tuntuvat osallistuvan erojen yksinkertaistamiseen. Leena-Maija Rossi kysyi SQS-lehdessä 2017 olisiko "käynyt niin, ettemme olekaan päässeet binääri-puusta kovinkaan pitkään? Onko kaksinapainen vastakkainasettelu kenties vain vahvistunut, kun meillä on nyt käytössä cis-etuliite, jolla kuvataan trans-positiolle vastakkaista asiaa”" (Rossi 2017). Sanoisin, että kyllä, juuri näin on tapahtunut. Huomioiko yleensä ulkopuolelta annettu cis-määritys sen, miten monella eri tavalla ihminen voi olla identifioitumatta lain määrittämään sukupuoleen tai varsinkaan niitä tapoja, joilla sukupuolen ilmaiseminen toisille voi ylittää normit myös trans-identiteetin ulkopuolella? Cis/trans-kahtiajako päätyy usein tukemaan juuri sellaista identiteettipolitiikkaa, jonka kritiikki on motivoinut sekä queer- että transteorian kehittymistä.

"Olisiko kolmannuudessa toiseutta purkavaa voimaa?" Pauliina Haasjoki kysyi $(2011,49)$ hahmottaessaan biseksuaalisuuden mahdollisuuksia suomalaisessa 1900-luvun kaunokirjallisuudessa. Purkavuuden ehtona on kuitenkin juuri monitulkintaisuuden säilyminen, sillä kuten Haasjoki kirjoittaa, "[k]ysymys seksuaalisuudesta asettuu kulttuurissamme muotoon 'kumpi', ja ambivalenssin paikka hupenee helposti kysymykseen 'kumpaa lähinnä”” (mt. 53). Biseksuaalisuuden tapaan muunsukupuolisuus on nykyhetkessä helposti trivialisoitavissa vain yhdenlaiseksi androgyyni-ihanteen myöhäismoderniksi versioksi, akateemisen maailman "muoti-ilmiöksi" tai yksilön elämän erääksi "vaiheeksi”.

Toisaalta, saavuttaessaan vakiintuneen aseman muunsukupuolisuuden kriittistä potentiaalia uhkaavat toiset asiat. Mikä estäisi sen, että kolmannesta sukupuolesta tulee uusi, harmillisella tavalla luonnollistava kategoria? Ehkä on naiivia olettaa yhden kategorian lisäämisen itsessään tuottavan niiden normien väljentymistä, joiden kautta sukupuolta voi tunnistettavasti ja kommunikoivasti performoida. Merkittävä muutos tarvitsisi tietysti järkevämmän määrän paitsi virallisia, myös symbolisesti tärkeitä ja merkitseviä sukupuolia - xenofeminismissä puhutaan bioteknisten interventioiden avulla saavutetuista sadoista (Laboria Cuboniks 2018), mutta sanotaan nyt vaikka 27. Tällöin kenenkään sukupuolesta olisi vaikea tehdä puolikkuutta, plus-miinuksisuutta, jonka mukaan ”jos et ole tätä niin sitten voit olla vain sitä".Jos utopioista keskustellaan, en tiedä kauniimpaa.

2010-luvun Suomessa queer on elänyt jo tovin identiteettinimikkeenä, osana LGTBQIA+ sateenkaarevuutta. Jokaisen identiteetin representoiminen edellyttää näkyvien ja yleensä ennalta koodattujen merkkien logiikkaan 
asettumista. On helppoa päätyä huolehtimaan siitä, onko "tarpeeksi" queer, eli välittääkö olemus tarpeeksi selväksi odotustenvastaisuutta, että voisi kutsua identiteettiä omakseen. Olisi outoa ironiaa, jos antinormatiivisuuden representoimisesta tulee työtä, jota uskottavasti queerin subjektin on tehtävä 24 tuntia vuorokaudessa. Identiteettien monistuminen ei sinällään vapauta tunteesta, että esimerkiksi ei-binäärisyyttä voi performoida oikein tai väärin.

Vapautumisen sijaan meitä ehkä vallitsee paljastumisen tai (värin) ymmärretyksi tulemisen pelko, kuten Turusen neitiherraa, joka ei kykene osallistumaan omien juhliensa seuraleikkiin: "MINÄ EN OSAA KEKSIÄ MITÄÄN TÄHÄN TYHJÄÄN LAPPUUN, KOSKA VOI OLLA, ETTÄ JOKU MIETTII, MITÄ KEKSIMÄNI SANA MINUSTA KERTOO.” $(2018,148$.

Tiedän, miten ylimielistä olisi huudella omasta positiostani käsin, että oikeastaan kukaan ei voi olla queer - varsinkin kun huomioi sanaan kirjautuneen historiallisen ja edelleen eri maailmankolkissa kaikuvan vihan ja pakotetun ulkopuolisuuden. Eihän minulla ole mitään oikeutusta väheksyä toisten taisteltuja ja heille tärkeitä identiteettejä. Silti toivon, että sukupuolista merkitsemistä pakoileva kirjoitus (ja luultavasti myös tietynlainen elo/kuvataide) antaisi hengitystilaa juuri identiteettipolitiikkaan liittyvistä paikantumisen pakosta. Monitulkintaisuus ei tällöin ole yksilön sisäinen ominaisuus, jotain saavutettavaa tai omistettavaa, vaan tapahtuma. Tekstin mahdollistamaa, edes lukemisen ajaksi meitä ympäröivästä sukupuolittamisesta vapauttavaa epämääräisyyttä.

Huomaan, että ongelmat ovat hyvin samanlaisia kuin ne, joita jo Eve Sedgwick pohti 1990-luvulla queer-teoriaa hahmottaneissa kirjoituksissaan ja joita Maggie Nelson pyrkii selvittämään 20 vuotta myöhemmin Argonauteissa. Miten tasapainotella monitulkintaisuuden ja strategisen essentialismin välillä? Onko suurempi paha siinä, että queer merkitsee jotain liian tiukasti vai siinä, että se lakkaa merkitsemässä jossain suhteessa lähtökohtaansa? Miten kunnioittaa ilmiöiden moninaisuutta tavalla, joka ei häivytä niiden poliittista merkitystä? (Ks. esim. Sedgwick 1993, 7-9; Nelson 2015, 28-30, 62, 111-113.)

\section{Miten teksti kirjoittaa lukijansa}

Taneli Viljanen on kenties se suomalainen nykykirjailija, joka on tuotannossaan johdonmukaisimmin ja monipuolisimmin pyrkinyt purkamaan sukupuolieron tavanomaisia representaatioita. Jo Viljasen varhaisissa novelleissa miesruumis esitetään absurdilla tavalla huokoisena ja aukkoisena. Esikoisromaanissa Toisto (2010) päähenkilö Markuksen anatominen sukupuoli konkreettisesti vaihtuu miehestä naiseksi ilman mitään luonnollistavia selityksiä. Riemastuttavaa on myös merkittävästä elämäntapahtumasta raportoimisen vähäeleisyys. Äkillinen muodonmuutos, jossa penis katoaa ja rinnat ilmestyvät, ei järkytä Markusta, koska hän on ”tässä vaiheessa vielä niin uninen" (Viljanen 2010, 123). Myöhemmin kertoja ihmettelee, miten hänen ystävänsä ei huomaa tätä:

Vasta laskeutuessani portaita tulin ajatelleeksi, ettei Veronika ollut huomauttanut mitään muutoksestani, se tuntui minusta oudolta. Mutta ehkä sukupuoli ei ollut hänelle niin tärkeä asia? Ehkä häntä oli ujostuttanut? Tai olisiko mahdollista, ettei hän ollut huomannut koko asiaa? Se tuntui uskomattomalta." (Viljanen 2010, 136.)

Tässäkin kohtaa Viljasen kerronta irrottautuu realistisen ja psykologisen kerronnan vaalimasta "uskottavuudesta", mutta tämä ei tyhjennä sukupuolitematiikkaa harmittomaksi erikoisuudentavoitteluksi. Pikemmin teksti pyrkii vieraannuttamaan jotain sukupuolitetun olemisen, tai sukupuolitetussa kehossa asumisen itsestäänselvyydestä, siitä että se merkitsisi jokaiselle samaa. Kuvaavaa on sekin, että koko sukupuolihankaluus ilmestyy 
vasta Markuksen miettiessä miltä näyttää toisille. Kuten myös Matinmikko $(2018,14)$ toteaa, Viljasen erikoiset tarina- ja kerrontaratkaisut ohjaavan pohtimaan tekstin ulkoista todellisuutta samaan tapaan "rakenteisena ja näkökulmittuneena”.

Myöhemmissä teksteissään kirjailija on siirtynyt tapaan kirjoittaa sukupuolisuus myös vähemmän tarinallisesti vaihtuvaksi ja jo perusolemukseltaan epämääräiseksi, jatkuvasti epäyhtenäiseksi. Esseessään Viljanen (2018) kysyy: "Kertooko epänormativisen sukupuolikokemuksen hahmottamisen vaikeus pohjimmiltaan siitä, että minkä tahansa ruumiillisen kokemuksen voisi myös jäsentää aivan toisin?" Viljasen kertovan proosan lukeminen tästä vinkkelistä auttaa huomaamaan, miten selvästi erikoisissa ja oudoissa sukupuolirajojen rikkomisissa on kyse juuri uusien jäsennysten etsimisestä. Tyylin kokeellisuus ja jatkuva sivupolkujen etsiminen suoralle representaatiolle tekevät hänestä kirjoittajan, jonka tuotantoa on mielekästä lähestyä queer-kerrontana, ei pelkästään queer-teemaisena.

Mietin esimerkiksi teosta Kaikki tilat ovat täynnä aaveita (2013), jossa kertomusta pyydetään ajattelemaan tilana. Proosan tarinallisia jaksoja kehystävät usein metafiktiiviset ja metakerronnalliset havainnot kirjoittamisen prosessista ja kertomusmuotojen poliittisuudesta. Ne muistuttavat myös viime vuosien autoteoriaksi ja teoreettiseksi proosaksi nimetystä, erityisesti feministisessä tutkimuksessa käsitellystä kirjallisuudesta. Teoksen loppupuolella esitetään kysymys siitä, tuliko lukija huomanneeksi ensimmäisen luvun henkilön sukupuolisen monitulkintaisuuden, ja jos ei, kenen vika se voisi olla. Lukijaa puhutellaan myös suoraan, oudontaen yleensä turvalliseksi koettua kirjaesineen välityksellä kommunikaatiota: "Entä miten voisin kirjoittaa sinut sukupuoleltasi vaihdettavaksi?" (Viljanen 2013,95 .) Kysymystä ei esitetä implisiittiselle queer-yleisölle vaan sen on tarkoitus hätkähdyttää jokaista tekstin lukijaa. Varsinkaan tässä yhteydessä vaihtaminen ei ole paha sana, jonka voisi korvata korjaamisella.
Vuonna 2019 Viljanen paikantaa itsensä muunsukupuoliseksi kirjailijaksi. Se on poliittisesti tärkeä teko, jota queer-tutkijan on syytä tukea siinä missä transmiehen ja transnaisen oikeuksia itsemäärittelyyn. Samalla huolestun siitä, että kun sukupuolivähemmistöön lukeutuvan kirjailijan tuotantoa lähestyy tekijän identiteetin kautta, lukija saattaa ohittaa mitä hänen tekstinsä kertovat kaiken ja itse kenenkin sukupuolitetun ruumiin outoudesta. Ongelma on tietenkin kaikkea muuta kuin uusi, ja liittyy myös queer-ja trans-tutkimuksessa käsitellyn kirjallisuuden kapeuteen. Johtaako sinänsä tuettava tarve etualaistaa ja tukea vähemmistöjen taidetta ja kulttuuria siihen, että tulkitsemme tekijän identiteetin ja tekstin välisen suhteen suoraviivaisesti syy-seuraus-suhteena?

\section{Lukemisen valinnoista}

Oma tutkijankoulutukseni ja intohimoinen suhteeni kaksinapaisuuden ylittämiseen ei ole tehnyt minusta välttämättä herkempää havaitsemaan tekstien monitulkintaisuutta. Esimerkiksi omassa kritiikissäni Ledasta vuonna 2017 olen kirjoittanut kertojahahmosta selvästi naisena - kenties siksi, että ensikohtaamisen aikana olin pitkään lukenut paljon lesboaiheiden käsittelystä vanhemmassa kirjallisuudessa, ja tekstin lukuisat pervot elementit oli helppo yhdistää tuohon lähtökohtaan. Oma torkahdukseni on osoittautunut opettavaiseksi myös siinä mielessä, että se auttaa muistamaan lukijan omien halujen vaikutuksen tulkintaan. On tärkeä kohdata se mahdollisuus, että päädyn lähes välttämättä tekemään "lukijan väkivaltaa sille seksuaalisuuksien moneudelle, välitilaisuudelle ja häilyvyydelle, joka ei ole välttämättä aina tunnistettavissa tai ainakaan nimettävissä" (Karkulehto 2007, 32). Lisäisin tuohon sukupuolen moneuden.

Olen viehättynyt siitä ajatuksesta, että queer-lukeminen voisi olla nimenomaan tarkkaa lukemista, palaavaa lukemista, joka tekee tu- 
tusta jälleen vierasta ehkä vähän keinotekoisenkin kysymisen kautta. Tässä mielessä se on hidasta, hieman yksinäistä löytöretkeilyä, jonka tuloksia on vaikea siirtää poliittisen aktivismin kieleen, mutta joilla on kiistaton poliittinen merkityksensä ankeasti ja maanisesti sukupuolitetun todellisuutemme monihahmotteisuuden osoittamisessa.

\section{Kirjallisuus}

Abbott, H. Porter. 2013. Real Mysteries. Narrative and the Unknowable. Columbus: The Ohio State University Press.

Butler, Judith. 2004. Undoing Gender. New York \& London: Routledge.

Fludernik, Monika. 1999. "The Genderization of Narrative." Teoksessa GRAAT 21: Recent Trends in Narratological Research, toimittanut John Pier, 153175. Tours: Publications des Groupes de Recherches Anglo-Américaines de l'Université Francois Rabelais.

Foucault, Michel. 2010 [1966]. Sanat ja asiat. Eräs ihmistieteiden arkeologia. Suomentanut Mika Määttänen. Helsinki: Gaudeamus.

Haasjoki, Pauliina. 2011. Häilyvyyden liittolaiset. Kerronnan ja seksuaalisuuden ambivalenssit. Annales Universitatis Turkuensis C 343 Turun yliopisto.

Hiidensalo, Venla. 2019. ”Onko kirjallisuudella sukupuolta?" Kirjailija, 15.3.2019. https://kirjailijaliitto.fi/kirjailija-lehti-artikkeli/onko-kirjallisuudellasukupuolta/ (luettu 30.5.2019)

Kaaja, Anu. 2017. Leda. Helsinki: Teos.

Karkulehto, Sanna. 2007. Kaapista kaanoniin ja takaisin. Johanna Sinisalon, Pirkko Saision ja Helena Sinervon teosten queer-feministisiä luentoja. Acta Universitatis Ouluensis B Humaniora 81. Oulu: Oulun yliopisto.

Laboria Cuboniks. 2018. The Xenofeminist Manifesto: A Politics for Alienation. https://laboriacuboniks.net

Lanser, Susan. 1996. "Queering Narratology.” Teoksessa Ambiguous Discourse: Feminist Narratology \& British Women Writers, toimittanut Kathy Mezei, 250-261. Chapel Hill \& London: University of North Carolina Press.

Lindstedt, Laura. 2019. Ystäväni Natalia. Helsinki: Teos.

Livia, Anna. 2001. Pronoun Envy. Literary Uses of Linguistic Gender. New York: Oxford University Press.
Marcus, Sharon. 2007. Between Women: Friendship, Desire, and Marriage in Victorian England. Princeton \& Oxford: Princeton University Press.

Matinmikko, Maria. 2018. "Taneli Viljasen tai(t)ava todellisuus". Teoksessa Suo, kuokka ja diversiteetti, toimittaneet Markku Eskelinen ja Leevi Lehto, 13-28. Helsinki: ntamo.

Matinmikko, Maria. 2019. Kolkka. Helsinki: Siltala.

Nelson, Maggie. 2015. The Argonauts. Minnesota: Graywolf Press.

Rossi, Leena-Maija. 2017. "Hauras, korjaava ja parantumaton queer - katse ylpeyden, normatiivisuuden ja (uus)häpeän aikoihin." SQS 1/2017.

Salamon, Gayle. 2010. Asssuming a Body. Transgender and the Rhetorics of Materiality. New York: Columbia University Press.

Sedgwick, Eve Kosofsky. 1993. Tendencies. Durham: Duke University Press.

Stryker, Susan. 2004. "Transgender Studies: Queer Theory's Evil Twin." GLQ: Journal of Lesbian and Gay Studies 10, no. 2: 212-215.

Säntti, Joonas. 2017. "Valloittavan pervoja maaseutukirjeitä". Kiiltomato, 8.6.2017. https://kiiltomato.net/anu-kaaja-leda/

Turunen, Eeva. 2018. Neiti U muistelee niin sanottua ihmissuhdehistoriaansa. Helsinki: Siltala.

Viljanen, Taneli. 2010. Toisto. Helsinki: Gummerus.

Viljanen, Taneli. 2013. Kaikki tilat ovat täynnä aaveita. Helsinki: Mahdollisen kirjallisuuden seura.

Viljanen, Taneli. 2017. Vyöhyke. Helsinki: Mahdollisen kirjallisuuden seura.

Viljanen, Taneli. 2018. "Aaveita, liukumia, muutoksia." Canth, 8.11.2018. http:// www.canthmag.fi/elama/aaveita-liukumia-muutoksia/ (luettu 30.5.2019).

Warhol, Robyn ja Susan Lanser. 2015. "Introduction". Teoksessa Narrative Theory Unbound. Queer and Feminist Interventions, toimittaneet Robyn Warhol ja Susan Lanser, 1-20. Columbus: Ohio State University Press.

Winterson, Jeanette. 1992. Written on the Body. London: Jonathan Cape.
SQS

$1-2 / 2019$ 